\title{
SCIENCE AND GOVERNMENT
}

$\mathrm{T}$

HE future of the relations between science and government formed the basis of several contributions at the Conference on Science and World Order organized by the Division for the Social and International Relations of Science of the British Association and held in London during September 26-28.

Sir Richard Gregory, president of the British Association, in opening the session, pointed out that men of science can no longer remain indifferent to the uses to which the powers created by their researches are put. They have the right and the responsibility to ensure that the fruits of their discoveries are not left entirely at the disposal of agencies which do not understand their nature or which misuse their promise.

Dr. J. Negrin, formerly professor of physiology in the University of Madrid, and lately head of the Spanish Republican Government, maintained that recovery, reconstruction and the laying of foundations for a lasting peace will depend fundamentally on a successful union between statesmanship and science. No less on this union depends the attainment of the immediate objective of victory in the present conflict, a victory without which our plans will be in vain. Between the statesman and science a dual relation is possible: a passive one, wherein the statesman incorporates learning, assimilates the scientific method, and becomes imbued with the scientific spirit; and an active one wherein he makes use of the teaching and progress of science.

The relation between science and government in Great Britain was discussed by Viscount Samuel. A year ago our resources of scientific knowledge and ability were still being very insufficiently used. Of late there has been a marked advance as seen in Lord Hankey's answer to a question in the House of Lords, in which he gave a full account of the numerous research bodies and advisory committees which serve as a link between scientific men and Government departments (see Nature, April 12, p. 432).

According to Prof. A. V. Hill, Foulerton professor of the Royal Society, there are Government establishments in which the spirit is a hundred per cent right; there are others in which it is miserably wrong. In the research establishments of the Ministry of Supply, the Scientific Advisory Council and its numerous committees, chiefly composed of independent men of science (including engineers), exert a considerable and beneficial influence. The Admiralty, on the other hand, with its traditional devotion to secrecy, has always resisted any suggestion that an advisory council containing independent men of science should be set up to take an interest in its research. In the Air Ministry and now in the Ministry of Aircraft Production the conditions are intermediate.

It is not necessary-indeed it would be absurd -to ask that an organization of the magnitude of the Scientific Advisory Council of the Ministry of Supply should be set up in every department ; but a panel of two or three independent advisers at least is necessary if opportunities are not to be missed. It is essential, if the scientific minds of workers in Government employment are to be saved from sterility, and their souls perhaps from damnation, that there should be as little distinction as possible between them and those in the universities, in industry, and in other independent institutions. In Great Britain we do not believe in bureaucracy. Our national genius has evolved a system by which the activities of officials are continually subject to the advice and help and criticism of public-spirited citizens.

Prof. J. B. S. Haldane, professor of biometry in University College, London, compared conditions in Great Britain with those of the U.S.S.R. $\mathrm{He}$ pointed out that in Great Britain the distinction between the pure or academic scientist and his industrial colleague is fairly sharp. In the Soviet Union the gap is bridged in several ways. The same man or woman may work in an industrial laboratory and in one devoted to 'pure' research or teaching. Laboratories engaged in 'pure' research are occasionally assigned certain technical problems.

To prevent the formation of a bureaucracy, the Soviet system is resorted to. The workers in laboratories, including technicians, frequently meet to discuss its problems. In this way centralization from above is balanced by initiative from below.

As Prof. Hill pointed out, there are several ways of ensuring that the initiative and keenness of Government-employed men of science do not become blunted. One may encourage junior and senior workers alike to interchange freely with other departments, with industrial laboratories, or with universities; one may provide facilities for visiting workers, for coloquia and discussion meetings, and for attendance at meetings of learned societies; one may adopt a system analogous to that of the reserve of officers and other ranks by which the Fighting Services prepare for times of emergency. Many of the ablest workers elsewhere would rightly value a period of service in Government laboratories. The plan for a reserve of officers and for frequent and regular interchange between different kinds of institutions need not be limited 
to science; it should be open to the Government service as a whole.

Mr. D. P. Riley, of the University of Oxford, speaking on the world planning of scientific research, put forward an eloquent plea for a greater share for the younger men of science in the counsels of scientific planning-a plea which it is hoped will receive sympathetic consideration. He suggested that as an essential supplement to present official plans, we put into direct contact with each other rank-and-file men of science in similar fields of science but working in different countries.

The past shortcomings of British colonial policy were discussed by Lord Hailey, who made several important suggestions for future consideration. It is advisable that the facilities afforded by all great imperial institutions of research should be utilized to the fullest extent and that the energies of colonial research workers should be strictly limited to problems requiring local inquiry. As Dr. Wilder Penfield, president of the Royal College of Physicians and Surgeons of Canada pointed out, if the universities of the United States and the Dominions were kept fully informed on all problems, they might well take up the torch of practical research.

The application of scientific organization to a department of State can be divided into five interlinked stages, according to Prof. J. D. Bernal, professor of physics in Birkbeck College. These are : (a) Information, where modern investigation, sampling and statistical methods are used to find the nature and extent of the needs to be satisfied: from this, by analysis, problems can be formulated. (b) Research, where the best answers to these problems can be arrived at. This involves a definite programme of work of every grade ranging from fundamental to ad hoc research, and good coordination between the different branches. (c) Development, where the solutions found are worked up into a state in which they can be used in practice. (d) Execution, or the putting of the plan into operation. (e) Control or the checking of the results by new statistical methods. This is a function of a control organization working in close conjunction with the information service.

The need for closer collaboration between Government design departments and people with production experience was emphasized by Dr. J. E. D. Swann, of the Association of Scientific Workers. Technical men on production or engaged on the development of Government designs frequently comment on the unsuitability of such designs for mass production. The necessity for changes is most appreciated by the younger men of science. Older men may dream dreams; but the younger men see visions of the immense possibilities inherent in science, and they must use this vision to remove the encumbrance of outworn traditions, to sweep aside the hindrances of selfish individualism, and to develop new methods of collaboration and planning. But as Prof. Hill said, if science be-. comes tied to emotion, to propaganda, to advertisement, to particular social or economic theories, it may cease altogether to have its general appeal, and its political immunity will be lost.

That emotion and intelligence, united in a common objective, obtain astounding results in thought, in action and in conduct was rightly claimed by Mrs. S. Neville-Rolfe, of the British Social Hygiene Council, who also pleaded for a fuller appreciation and utilization of youth in helping to muster the forces of evolution and directing them to the development of man.

There is an overwhelming need for collating, interpreting and applying the various discoveries and concepts in biology, psychology, physiology, anthropology and sociology-branches of knowledge so pitifully ignored by communities and governments. The science of social biology is scarcely recognized at present ; but it is one which will need to be incorporated in whatever form the policy of world reconstruction and re-planning takes after the War. In fact, the main problems of social biology are immediate, though they may take a rather modified form during the War.

As Prof. Hill stated, the deliberate application of science in government is a new method; it has never been properly or whole-heartedly tried. If it is to have a chance of success now, it must be saved from the start from sloppy thinking, careless handling or unscrupulous use. Nevertheless, Dr. Negrin stated that in periods of transition and readjustment, such as the present, science provides the statesman with a means by which he can discriminate the noxious from the sound. It provides the touchstone to reveal the senescence of traditions and to point out those which should be removed. Science can help the statesman to remove antagonism in social life and contradictions in individual conduct and collective behaviour ; also to correct professional deformations in the statesman himself, by maintaining a balance in his qualities.

It is the duty of science to share actively in the search for remedies. Viscount Samuel pointed this out and added that religion and philosophy are engaged in the same quest. Only when all three recognize that they are interdependent and move together in search of the common goal will the problems of our troubled age approach their solution.

From the above contributions alone, it is seen that the commonwealth of science is a true democracy, and must, therefore, take its right place in the counsels of the world for re-planring democracy when the time comes. 